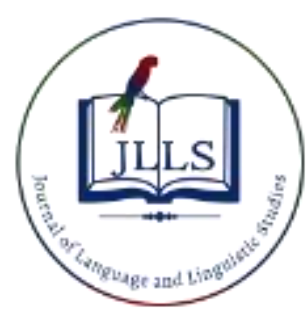

Available online at www.jlls.org

JOURNAL OF LANGUAGE

AND LINGUISTIC STUDIES

ISSN: $1305-578 \mathrm{X}$

Journal of Language and Linguistic Studies, 16(2), 798-808; 2020

\title{
A validity and reliability study of the scale of teacher candidate beliefs about
}

\section{Ottoman Turkish}

\author{
Bekir Kayabaşı a 1 (iD) \\ APA Citation: \\ a, Adlyaman University, Adlyaman, Turkey \\ Kayabası, B. (2020). A validity and reliability study of the scale of teacher candidate beliefs about Ottoman Turkish. Journal of Language and \\ Linguistic Studies, 16(2), 798-808. \\ Submission Date:05/01/2020 \\ Acceptance Date:26/02/2020
}

\begin{abstract}
The aim of this study is to develop a scale of pre-service teacher beliefs about Ottoman Turkish. The 34-item "The Scale of Teacher Candidate Beliefs about Ottoman Turkish," created for the piloting was given to 202 pre-service teachers who were taking an Ottoman Turkish course in the departments of Turkish education and Arabic education at Adiyaman University Faculty of Education, to determine the factor structure of the scale. Exploratory and confirmatory factor analyses were performed on the data, and a 14-item scale consisting of alphabet, reading, writing and grammar sub-dimensions was obtained. The total variance explained by the scale was calculated to be $44.69 \%$. The internal consistency value of the Scale of Teacher Candidate Beliefs about Ottoman Turkish was found to be .84 . Thus, a functional scale serving the purpose of the study was developed.
\end{abstract}

(C) 2020 JLLS and the Authors - Published by JLLS.

Keywords: Ottoman Turkish; scale development; beliefs.

\section{Introduction}

\subsection{The History of Ottoman Turkish Alphabets}

The original speakers of the Turkish language lived in Central Asia. They roamed as nomads over a vast region that today covers Siberia, Western China, Kazakhstan, Kyrgyzstan and nearby regions. They were known at an early time to both the Chinese and the Middle Eastern Persian and Arabs, but they first appeared in large numbers as nomadic soldiers in the Middle East in the tenth century. Following the arrival of Arab conquerors in Central Asia, a vast majority of Turks in the region had converted to Islam over the course of several hundred years. Although some of the Turks in history had been Christians and Jews, Islam became the religion of the majority and remains so today (McCarthy \& McCarthy, 2010, p. 4)

Turks have used many alphabets throughout their history. Among these alphabets, they used the Ottoman Turkish alphabet which was formed with four or five letters added to the Arabic alphabet for a thousand years, and created a library of hundreds of thousands of works in different written dialects

\footnotetext{
${ }^{1}$ Corresponding author. Tel.: +90 4162233800

E-mail address: bkayabasi@hotmail.com
} 
of Turkish. The use of the Arabic alphabet is not only a decision made by the ruler, but rather an adoption by the new Muslims who wanted to learn the Arabic alphabet to read the book of their new religion, and began to write their own language with the Arabic alphabet. Throughout the entire Mavera-un-nehir basin where Turks converted to Islam, Turkish texts were created by using the Arabic letters. The Persians who adopted Islam a century before the Turks had adapted the Arabic alphabet to their own written language.

Turks, like Muslims, adapted the basic calligraphy of their religion, and stressed the Arabic script as the noblest of the art forms. Primarily, the art of calligraphy was held in the highest esteem because it was used to transcribe the Word of God, or "Qoran," the Holy Book of the Muslims. Turks used the Arabic script until they adopted the Latin alphabet in 1928 (McCarthy \& McCarthy, 2010, p. 233).

The alphabet used by the Turks was the alphabet used by the Arabs in which all the primary sources of Islam were written. Certainly, although the Arabic alphabet was ideal for the natüre of the Arabic language, it took a long time for it to adapt to the nature of Turkish. Arabic is a Semitic language, which has historically been formed of two main forms: South Arabic and North Arabic. The Southern form is found in the Old South Arabia and includes, among others, the Sabaean and Hmyaritic languages which we know of through inscriptions dating from the pre-Christian era, the 6th century AD (Al-Ani, 1970, p. 17).

With the spread of Islam, Arabic has become an imperial language. This great empire, based on a religion, ruled a vast area from Central Asia to Spain. The vast nature of the empire required civil servants to combine a good knowledge of literary Arabic with a wide range of other subjects. Knowledge of fiqh (Islamic law) was necessary as the official basis of social order, but at the same time, the civil servant was also expected to know pre-Islamic poetry and command a broad understanding of history and geography, courtly precedents, literary allusions and the natural sciences (Burrows, 2016, p. 11).

\subsection{Turkish Script Reform}

All innovations seem to have started within the military system. It can be said that, throughout the 19th century, soldiers felt the necessity of literacy the most. Many issues such as adapting soldiers to changing technology and understanding written commands required literacy for the military. Therefore, it is the soldiers who reflected the most deeply about the Turkish language. The Arabic-Persian letters began to be seen as unsuitable for writing Turkish and was blamed for the extremely low level of literacy among the Turks. Some reformers considered simplifying the alphabet to make Turkish easier to read and write. Enver Pasha, who became the minister of war in 1914, produced such an alphabet to increase literacy in the army. But few considered abolishing the script and adopting one that was so totally alien (Ahmad, 2002, p. 80).

The solution sought by Enver Pasha by using the Ottoman Turkish failed to produce satisfactory results, so the Arabic alphabet was abandoned in 1928. Only after the opposition had been crushed could Mustafa Kemal think of imposing this measure on the nation. As a trial run, the Western numerals replaced the Arabic numerals in May 1928. Mustafa Kemal then began to demonstrate the new Latin script in public throughout the country. Finally, on 1 November 1928, the Turkish parliament passed the law introducing the new Turkish alphabet which was to be used in all publications from the beginning of the New Year (Ahmad, 2002, p. 81). There was an elite class of intellectuals living in the Soviet region who used the Latin alphabet, some of whom were exiled to Turkey. It can be said that there was a proper environment. The ideological level of readiness for the alphabet change in Turkey can be said to be convenient at the time. In 1926, the Soviets introduced some modified Latin alphabets for the Turkic languages of Central Asia. This helped strengthen support for the adoption of the Latin alphabet 
in Turkey, and exiles from Azerbaijan were actively involved in pushing for the switch (Johnson, 2004, p. 77).

\subsection{Teaching Ottoman Turkish as an Archaic Alphabet in Modern Turkey}

Since 1928, Ottoman Turkish has not been used as the official communication tool in Turkey. However, as the heir of a great historical background, the modern Turkey has continued to teach the Arabic alphabet at the academic level to preserve that heritage. Whether a researcher or an ordinary reader, anyone interested in learning more about Turkey's past needs Ottoman Turkish.

Today, along with increased levels of literacy and extremely easy access to information, the use of the Internet in general and the social media in particular has increased the need for individual access to information to an unprecedented extent. The frequent use of social media has bolstered a sense of personal chronology and aroused a stronger interest in history in ordinary people. The shift from personal chronology to the national past drives this strong interest in the tools for learning the past. To be able to read Ottoman Turkish means the ability to use a large library of Turkish history. No great opportunity can be realized without overcoming huge obstacles, and this obstacle preventing access to Turkish history, literature and ethnography is undoubtedly the lack of proficiency in Ottoman Turkish.

Excluding the private courses in Turkey, Ottoman Turkish is taught in the university departments of Turkish Language and Literature, History, and Turkish Education. The Arabic alphabet, which was taught as the primary alphabet before 1928, is now taught as the secondary alphabet. The teaching process and tools of Ottoman Turkish, which is taught to the students who have learned to read and write in Latin alphabet, have yet to be carried out within the framework of today's educational sciences. So much so that even student beliefs about learning Ottoman Turkish have not yet been questioned, and the academic system of teaching it has been in place for almost 90 years.

\section{Method}

This study is a scale development study. The stages of developing the The Scale of Teacher Candidate Beliefs about Ottoman Turkish and the characteristics of the study group are presented below.

\subsection{Sample / Participants}

Characteristics of the sample group of the study is as follows:

Table 1. Demographic characteristics of the sample group

\begin{tabular}{lcc}
\hline \multicolumn{1}{c}{ Gender } & $n$ & $\%$ \\
$\quad$ Female & 151 & 74.8 \\
$\quad$ Male & 51 & 25.2 \\
Class Level & & \\
1st Year & 42 & 20.8 \\
2nd Year & 75 & 37.1 \\
3rd Year & 41 & 20.3 \\
4th Year & 44 & 21.8 \\
Department & & \\
$\quad$ Turkish Language Teaching & 165 & 81.7 \\
Arabic Language Teaching & 37 & 18.3 \\
\hline
\end{tabular}


The participants of the study consisted of 202 students attending Adiyaman University Faculty of Education and taking an Ottoman Turkish course. 151 (74.8\%) of the participants were female and 51 $(25.2 \%)$ were male. The ages of the participants ranged between 17 and $38(\mathrm{M}=20.831, \mathrm{SD}=2.307)$. $81.7 \%$ of the students were studying Turkish language teaching and $18.3 \%$ were studying Arabic language teaching. In addition, 20.8\% of the students were first year (freshman) students, $37.1 \%$ were in their second year (sophomores), 20.3\% were in their third year (juniors), and $21.8 \%$ were senior students (See Table 1). Since the Arabic language teaching department students taking the Ottoman Turkish course were in their seconds year of study, they had a higher number than the other classes participating in the study. Students who voluntarily participated in the study were informed about the purpose of the study and the data collection tool before the study.

\subsection{Developing the Scale of Teacher Candidate Beliefs about Ottoman Turkish}

The main purpose of this study was to develop a scale of pre-service teacher beliefs about Ottoman Turkish. For this purpose, four faculty members teaching an Ottoman Turkish course at a Faculty of Education were interviewed about Ottoman Turkish and students who were learning Ottoman Turkish were observed. However, since there was no scale study on the beliefs of the students in Ottoman Turkish and the Ottoman Turkish alphabet is Arabic-based, the literature of teaching Arabic as a foreign language was reviewed (Al-Ani 1970, Al-Hattami, 2000, Burrows 2016). An item pool was created in line with the information obtained from the interviews, observations and literature review. Then, expert opinion was obtained from four faculty members teaching Ottoman Turkish. In line with the the expert opinions, the items were revised and the items that were found inadequate for the study were removed. In accordance with the expert opinions, a scale with 34 items was created. It was decided that the scale form consisting of 34 items should be 5-point Likert type. The 5-point Likert form consisting of 34 items was then given out to the pre-service teachers who were learning Ottoman Turkish in Turkey.

\subsection{Data Analysis}

First, the exploratory factor analysis was conducted to determine the factor structure of the scale. Using the principal component factorization method, the maximum variability (Varimax) was applied as the rotation. The items with a factor load value of .40 and above were included in the analysis. To determine the overlapping items, the value of .32 was taken as the basis (Çokluk, Şekercioğlu and Büyüköztürk, 2012; Tabachnick and Fidell, 2013). In addition, the factor structure of the scale determined by the exploratory factor analysis was tested by second-order confirmatory factor analysis. The ratio of the chi-square to the degree of freedom $(\chi 2 / s d)$, the approximate square root of approximate errors (RMSEA), the comparative agreement index (CFI), the standardized residual averages (SRMR) and the Tucker-Lewis index (TLI) were used to evaluate the measurement model. It was used. Less than $5 \chi 2 /$ sd ratio, .08 or lower RMSEA and SRMR values indicate good compliance, while .90 or higher CFI and TLI values indicate acceptable compliance (Hooper, Coughlan and Mullen, 2008; Kline, 2005). Finally, the internal consistency $(\alpha)$ and item total correlation values were examined for the reliability analyses of the scale. All the data analyses were performed by running the SPSS25 and AMOS 24 programs.

\section{Results}

\subsection{Factor Structure of the Scale}

The exploratory factor analysis was applied to test the factor structure of the scale. The suitability of the data for the factor analysis was examined by applying the Kaiser-Meyer-Olkin and Bartlett tests. 
The results of the factor analysis showed that the Bartlett test for the 34-item the Scale of Teacher Candidate Beliefs about Ottoman Turkish Scale were statistically significant $\left(\chi^{2}=2646.352\right.$, $\mathrm{sd}=561$, $\mathrm{p}<.001$ ) and the Kaiser-Meyer-Olkin value for the sample size was .842. That the Bartlett test result is significant and the Kaiser-Meyer-Olkin value is .60 and above (Tabachnick and Fidell, 2013) show that the data structure is suitable for factor analysis. The scree plot showing the factor structure of the scale is presented in Figure 1.

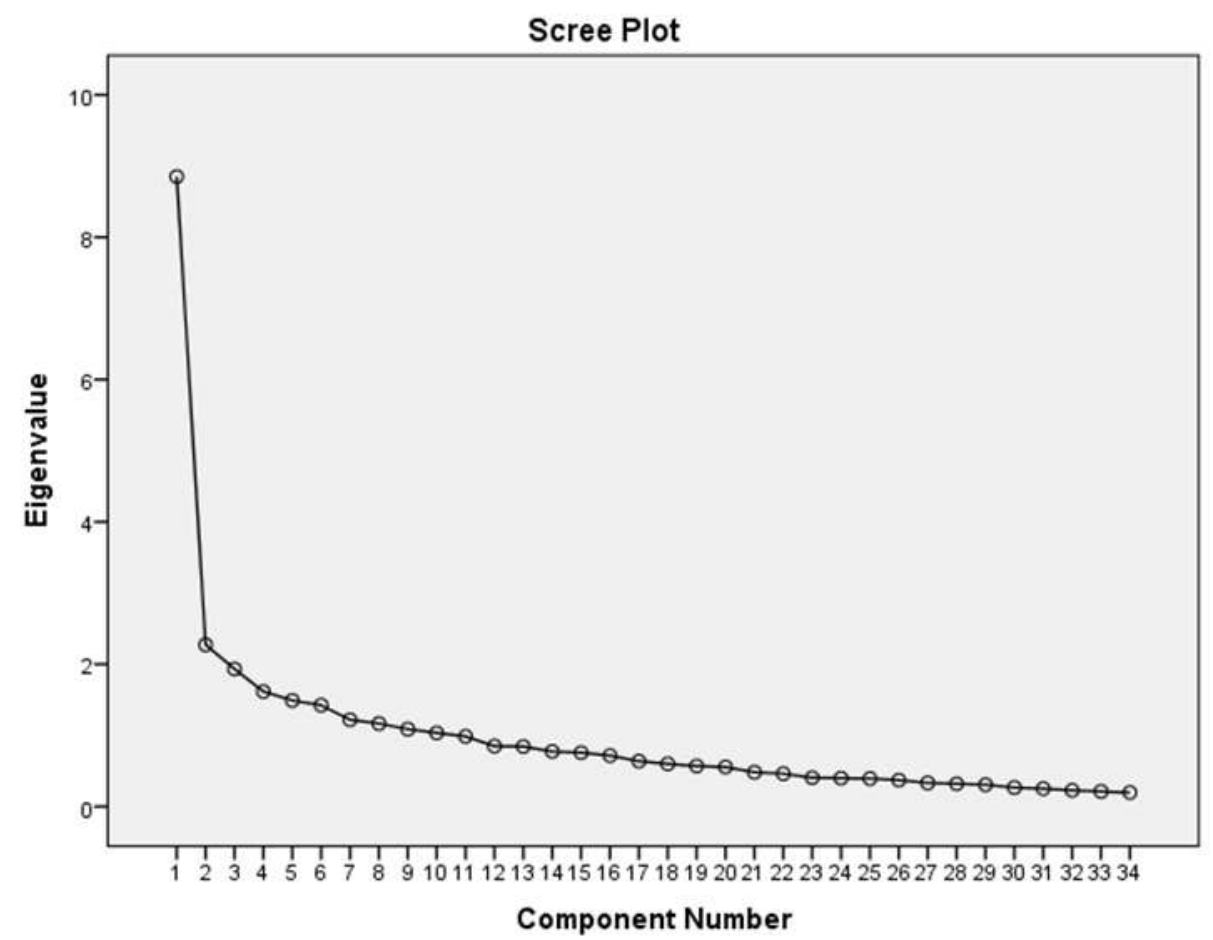

Figure 1. Scree plot for the scale

The principal component analysis and maximum variability were used as the exploratory factor analysis factorization technique. In determining the factor structure, eigenvalue of 1 and above was taken as the criterion. In addition, the scree plot of the scale's factor structure was also examined. The results of the exploratory factor analysis showed that the 34-item scale had a 10-factor with an eigenvalue greater than 1 and explaining $64.983 \%$ of the total variance. The eigenvalues of the scale ranged between 1,035 and 8,852. When the scree plot of the scale given in Figure 1 is examined, it is clear that the scale has a structure of two or three factors. In particular, the significant decrease in the eigenvalue of the scale structure after the second factor supports this conclusion. Therefore, firstly, items with a load value of .32 and above and a factor load of less than .40 were excluded from the analysis (Tabachnick and Fidell, 2013). The factor analysis was renewed for each item by excluding these items respectively. When the analyses were renewed according to the determined criteria, the scale produced 14 items under two sub-dimensions. The exploratory factor analysis results related to the factor structure of the scale are given in Table 2. 
Table 2. The Results of Analysis of Factor Structure of the Scale

\begin{tabular}{|c|c|c|c|c|}
\hline & \multicolumn{4}{|c|}{$\begin{array}{l}\text { Factorial Structure of the } \\
\text { Scale }\end{array}$} \\
\hline & $\begin{array}{c}\text { Factor } \\
1\end{array}$ & $\begin{array}{l}\text { Factor } \\
2\end{array}$ & h2 & $\mathrm{r}$ \\
\hline $\begin{array}{l}\text { The fact that the alphabet used in Ottoman Turkish is very different from the alphabet } \\
\text { we read and write prevents us from learning. }\end{array}$ & .785 & & .624 & .652 \\
\hline $\begin{array}{l}\text { The fact that there are phonemes that are not written in Ottoman Turkish but which } \\
\text { should be taken into consideration while reading makes it difficult to learn. }\end{array}$ & .779 & & .608 & .633 \\
\hline Changes in the spelling of letters in Ottoman Turkish in words prevent learning. & .765 & & .633 & .687 \\
\hline $\begin{array}{l}\text { Having more than one letter for a phoneme in Ottoman Turkish makes learning } \\
\text { difficult. }\end{array}$ & .761 & & .636 & .667 \\
\hline The shapes of the letters are very similar in Ottoman Turkish. & .560 & & .340 & .467 \\
\hline I think there are too many dotted letters in Ottoman Turkish. & .539 & & .303 & .417 \\
\hline I think it is easy to write the letters in Ottoman Turkish. & .513 & & .325 & .434 \\
\hline It is not possible to speak in Ottoman Turkish with a standard spelling. & & .704 & .500 & .445 \\
\hline $\begin{array}{l}\text { It is a great difficulty to figure out the Persian phrases in Ottoman Turkish texts on } \\
\text { the basis of meaning. }\end{array}$ & & .615 & .407 & .457 \\
\hline $\begin{array}{l}\text { When writing in Ottoman Turkish, the writing of the vowels of Turkish words } \\
\text { becomes a problem. }\end{array}$ & & .421 & .385 & .482 \\
\hline It is difficult to learn the cursive forms of Ottoman Turkish. & & .478 & .454 & .525 \\
\hline In Ottoman Turkish, recognizing the letters is not enough to read the words. & & .586 & .350 & .400 \\
\hline Different spelling forms of the Turkish words negatively affect word recognition. & & .545 & .310 & .386 \\
\hline $\begin{array}{l}\text { While reading words in Ottoman Turkish, reading by guessing, and not seeing the } \\
\text { vowels, makes the learning process difficult. }\end{array}$ & & .494 & .323 & .420 \\
\hline Explained Variance $(\%)$ & 25.333 & 19.362 & & \\
\hline Eigenvalue & 4.561 & 1.697 & & \\
\hline Internal consistency $(\alpha)$ value & 82 & .73 & .8 & \\
\hline
\end{tabular}

Note. $\mathrm{h} 2=$ Factor common variance, $\mathrm{r}=$ Item total correlation values

The results of the exploratory factor analysis showed that the scale had a 14-item two-dimensional structure with an eigenvalue of more than 1. These two dimensions explained $44.695 \%$ of the total variance. In the first dimension of Alphabet, 7 items with an eigenvalue of 4.561 were included and explained $25.333 \%$ of the total variance. The factor load values of the items related to this factor ranged from .513 to .785 . The second dimension of the scale (Reading, Grammar and Writing) included 7 items with an eigenvalue of 1.697, and these items explained $19.362 \%$ of the total variance. The load values for this factor range from .494 to .704 . Two of the items in this scale relate to reading beliefs, two to grammar and three to writing beliefs.

The second confirmatory factor analysis was performed to test the factor structure of the 14 items obtained by exploratory factor analysis. Measurement model and standardized factor load values for the confirmatory factor analysis are given in Figure 2. 


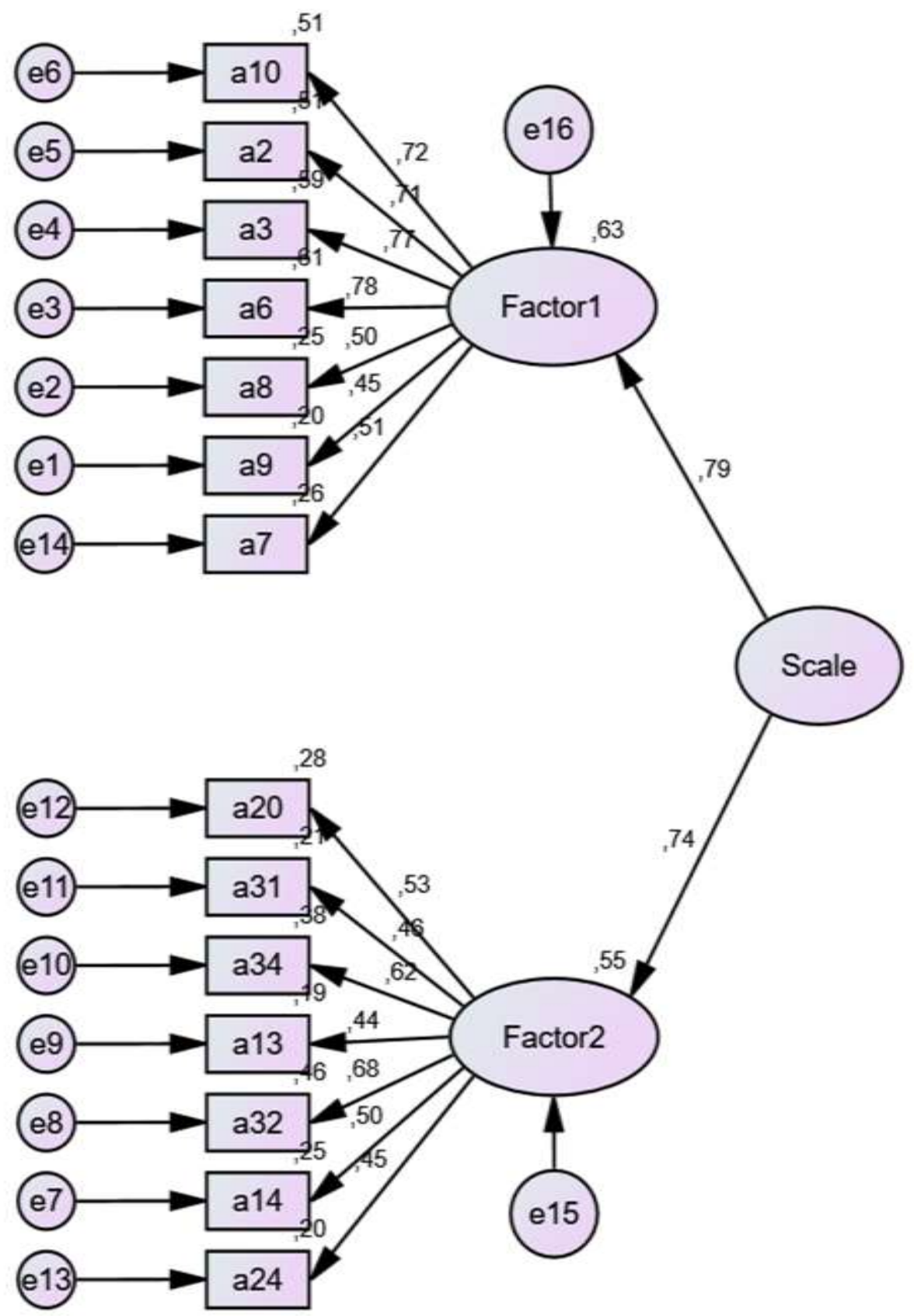

Figure 2. Second Level Confirmatory Factor Analysis Results

Note . Factor 1 = Alphabet, Factor $2=$ Reading, Grammar and Writing Scale, Scale $=$ Developing the Scale of Teacher Candidate Beliefs about Ottoman Turkish

The standardized factor loads for the scale ranged from .45 to .78 for the alphabet subscale, and .45 to .68 for the reading, grammar and writing subscale. However, the results of the analysis showed that the 14 items and two sub-factors of the Scale of Teachers Candidate Beliefs about Ottoman Turkish produced a good level of fit value. The results showed that the value of $\chi^{2}$ was 127.289 and significant $(\mathrm{p}<.001)$. The ratio of $\chi^{2}$ to freedom degree $(127.289 / 76)$ was found to be 1.67 . When the ratio of this 
value to the degree of freedom is less than 2, it is considered as a perfect fit (Kline, 2005). Furthermore, the other values were found to be as follows: $\mathrm{RMSEA}=.057, \mathrm{CFI}=.93, \mathrm{TLI}=.92$ and $\mathrm{SRMR}=.059$. RMSEA and SRMR values of .08 and below indicate good fit, whereas CFI and TLII values of .90 and higher indicate acceptable fit (Hooper et al., 2008; Kline, 2005). Therefore, these results showed that the scale produced good fit values.

\subsection{Descriptive Statistics and Reliability Analysis}

A correlation analysis was conducted to examine the relationship between the subdimensions of the scale. The mean and standard deviation values were calculated as part of descriptive statistics. The descriptive statistics and correlation analysis results related to the total and factors of the scale are presented in Table 3.

Table 3. Relationship between the Factors of the Scale

\begin{tabular}{lccc}
\hline Scales & 1. & 2. & 3. \\
\hline 1. Alphabet Scale & - & $.467^{* *}$ & $.882^{* *}$ \\
2. Reading, Grammar and Writing Scale & & - & $.829^{* *}$ \\
3. Scale Total & & - \\
Mean & 21.777 & 23.539 & 45.316 \\
Standard deviation & 6.929 & 5.844 & 10.955 \\
\hline${ }^{* *}<01$ & & &
\end{tabular}

For the reliability analysis of the scale, internal consistency $(\alpha)$ and item total correlation values were calculated. The internal consistency value of the scale was .82 for the alphabet subdimension, .73 for the reading, grammar and writing subdimension, and .84 for the overall scale. The internal consistency value of .70 and above is accepted as a good reliability level (Büyüköztürk, 2010). The item total correlation values of the scale ranged from .386 to .687 . The internal consistency and item-total correlation values of the scale are presented in Table 2.

Finally, the beliefs of the participants regarding Ottoman Turkish were examined in terms of gender, year of study and department. For this purpose, t-test and one-way variance analysis (ANOVA) were performed for independent samples. No statistically significant difference was found by gender in terms of the alphabet $(\mathrm{t}=-.008, \mathrm{p}=.993)$, reading, grammar and writing $(\mathrm{t}=-1.740, \mathrm{p}=.083)$ and the total scale $(\mathrm{t}=-.929, \mathrm{p}=.354)($ see Table 4$)$.

Table 4. Analysis RESULTS RELATED TO GENDER AND EDUCATION LEVEL

\begin{tabular}{|c|c|c|c|c|}
\hline Gender & & Mean & $S D$ & $t$ \\
\hline \multirow[t]{2}{*}{ Alphabet } & Female & 21.774 & 7.064 & -.009 \\
\hline & Male & 21.784 & 6.579 & \\
\hline \multirow[t]{2}{*}{ Reading. Grammar and Writing } & Female & 23.125 & 5.681 & -1.740 \\
\hline & Male & 24.764 & 6.198 & \\
\hline \multirow[t]{2}{*}{ Scale Total } & Female & 44.900 & 11.077 & -.929 \\
\hline & Male & 46.549 & 10.596 & \\
\hline \multicolumn{5}{|l|}{ Department } \\
\hline \multirow[t]{2}{*}{ Alphabet } & Turkish & 22.642 & 6.999 & $3.876^{* *}$ \\
\hline & Arabic & 17.918 & 5.117 & \\
\hline Reading. Grammar and Writing & Turkish & 24.406 & 5.697 & $4.675^{* *}$ \\
\hline
\end{tabular}




\begin{tabular}{llccc}
\hline & Arabic & 19.675 & 4.904 & \\
Scale Total & Turkish & 47.048 & 10.578 & $5.022^{* *}$ \\
& Arabic & 37.594 & 9.238 & \\
\hline
\end{tabular}

*** $p<.001$

There was a statistically significant difference between the participants regarding the subdimensions of alphabet $(\mathrm{t}=3.876, \mathrm{p}<.001)$, reading, grammar and writing $(\mathrm{t}=4.675, \mathrm{p}<.001)$, and the overall scale $(\mathrm{t}=5.140, \mathrm{p}<.001)$. The students in the Turkish Language Teaching were observed to have a significantly higher average score than those studying Arabic Language Teaching in the total of the scale, as well as the alphabet, and reading, grammar and writing subdimensions.

Table 5. Results of the year of study analysis

\begin{tabular}{llcccc}
\hline Year of Study & & Mean & SD & $F$ & Comparison \\
\hline Alphabet & 1st Year & 22,714 & 7,228 & $5.259^{*}$ & \\
& 2nd Year & 19,480 & 6,275 & & $2<3$ \\
& 3rd Year & 24,292 & 6,253 & & \\
& 4th Year & 22,454 & 7,340 & & $2<1$ \\
Reading, Grammar and & 1st Year & 24,523 & 5,976 & $5.785^{* *}$ & $2<3$ \\
Writing & 2nd Year & 21,493 & 6,009 & & $2<1$ \\
& 3rd Year & 25,658 & 6,002 & & $2<3$ \\
Total & 4th Year & 24,113 & 4,132 & & $2<4$ \\
\hline
\end{tabular}

$* \mathrm{p}<.051, * * \mathrm{p}<.001$

According to the year of study, there was a statistically significant difference between the participants regarding the alphabet $(\mathrm{F}=5.259, \mathrm{p}<.05)$, reading, grammar and writing $(\mathrm{F}=5.785, \mathrm{p}<.001)$ and the total scale $(F=7.696, p<.001)$. Tukey's multiple comparison tests were performed to see which classes the difference was between. The sophomores had a lower average score than the juniors in the alphabet subdimension, and they had lower scores than the freshmen and juniors in terms of the reading, grammar and writing subdimension. For the overall scale, the sophomores had a significantly lower average score than freshmen, juniors and seniors (See Table 5).

\section{Conclusions}

This study aimed to develop the Scale of Teacher Candidate Beliefs about Ottoman Turkish. First of all, an item pool was created by performing interviews, observations and a review of the related literature. After obtaining expert opinion on this item pool to ensure content validity, the items were converted into a draft form consisting of 34 items. This draft form was voluntarily completed by 202 pre-service teachers who were taking an Ottoman Turkish course in the departments of Turkish 
Language Teaching and Arabic Language Teaching at Adiyaman University Faculty of Education. The validity and reliability analyses of the scale were performed based on the obtained data.

According to the results of exploratory and confirmatory factor analysis conducted to determine the construct validity of the scale, a 14-item scale consisting of Alphabet and Reading-Writing-Grammar sub-dimensions was obtained. This scale can be administered to the learners of Ottoman Turkish and their beliefs about Ottoman Turkish can be determined in advance, revealing whether they have negative beliefs specifically about the alphabet or about the reading-writing-grammar. Thus, various instructional proactive actions can be taken to improve the process of teaching Ottoman Turkish.

\section{Ethics Committee Approval}

The author(s) confirm(s) that this study does not need ethics committee approval (Date of Confirmation: 10.03.2020).

\section{References}

Ahmad, F. (2002). The making of modern Turkey. London-Newyork.

Al-Ani, S. H. (1970). Arabic phonology. Paris.

Burrows, G. (2016). The politics of Arabic script. Australian National University.

Büyüköztürk, Ş. (2010). Sosyal bilimler için veri analizi el kitabı: İstatistik, araştırma deseni, SPSS uygulamalart ve yorum. Ankara: Pegem Akademi

Calp, M. (2019). An investigation on the regulation and responsibilities of reading and writing failures against Ottoman Turkish language students. Kastamonu Education Journal. 27(4), 1757-1776.

Çokluk, Ö., Şekercioğlu, G. ve Büyüköztürk, Ş. (2012). Sosyal bilimler için çok değişkenli istatistik: SPSS ve LISREL uygulamaları. Ankara: Pegem Akademi.

Hooper, D., Coughlan, J., \& Mullen, M. R. (2008). Structural equation modelling: guidelines for determining model fit. Electronic Journal of Business Research Methods, 6(1), 53-60.

Jais, M. (2018). Orthographic Transparency the Ottoman Abjad. Retrieved From https://ufdc.ufl.edu/AA00063171/00001

Jessen, A. L. (2017). The sociolinguistic role of Ottoman Turkish and Arabic Turkish nationalism. İstanbul: Sabanc1 University.

Johnson, A. (2004). The road to Turkish language reform and the rise of Turkish nationalism. McGill University.

Karadoğan, A. (2017). Arap harfleri ve Osmanlı Türkçesi. Türk Dili, 68(791), 1-8.

McCarthy, J., \& McCarthy, C. (2010). Turkey and Turks. Turkish Cultural Foundation.

Melenkaya, K. A., \& Zhbannikova, M. I. (2017). Contemporary Turkish Language: Historical- CulturalAspects. Научный алманах стран причерноморья.

Tabachnick, B. G., \& Fidell, L. S. (2013). Using multivariate statistics. Boston, MA: Pearson Education, Inc.

Y1lmaz, K. (2011). Critical examination of alphabet and language reforms implemented in the early years of the Turkish republic. Journal of Social Studies Education Research. 2(1), 59-82. 


\section{Osmanlı Türkçesi ile ilgili öğretmen adayı inançlarının geçerliliği ve güvenilirliği çalışması}

\section{$\ddot{O} \mathbf{z}$}

Bu çalışmanın amacı, Osmanlı Türkçesi ile ilgili öğretmen adaylarına yönelik bir ölçek geliş̧irmektir. Adıyaman Üniversitesi Eğitim Fakültesi Türkçe eğitimi ve Arapça eğitimi bölümlerinde Osmanlı Türkçe dersi alan 202 öğretmen adayına pilot uygulama olarak oluşturulan 34 maddelik "Osmanlı Türkçesine İlişkin Öğretmen Aday İnançları Ölçeği” ölçeğin faktör yapısını belirlemek için verilmiştir. Veriler üzerinde açımlayıcı ve doğrulayıcı faktör analizleri yapılmış ve alfabe, okuma, yazma ve dilbilgisi alt bölümlerinden oluşan 14 maddelik bir ölçek elde edilmiştir. Ölçeğin açıkladığı toplam varyans\% 44,69 olarak hesaplanmıştır. Öğretmen Aday İnançları Ölçeği'nin Osmanlı Türkçesi ile ilgili iç tutarlılık değeri .84 olarak bulunmuştur. Böylece çalışmanın amacına hizmet eden fonksiyonel bir ölçek geliştirilmiştir.

Anahtar sözcükler: Osmanlı Türkçesi, Ölçek geliştirme, inançlar

\section{AUTHOR BIODATA}

Bekir Kayabaşı works as an Assist. Prof. Dr. in Education Faculty of Adıyaman University. He graduated from the Ankara University, Faculty Of Language History and Geography, the department of Turkish Language and Literature. He recieved his degree in Phd from the University of İnönu. 